\title{
Parents' Engagement in Mathematics Learning Among Deaf Child
}

\author{
Liong Kon Thai, Mohd Hanafi Mohd Yasin
}

National University of Malaysia, 43600 Bangi, Selangor, Malaysia. E-mail: ktliong@yahoo.com

\begin{abstract}
Mathematics across most of the school's subjects. The cross-sectional survey of mix method sequential explanatory was held to aim in collecting parents' engagement in mathematics learning among deaf child from eleven constructs namely mathematical media resources support, encouragement, involvement in child's mathematical activity, learning of mathematics experience, reading mathematical materials with child, conducive learning environment, recognition and reward, affection, expectation of child's mathematics achievement, child acceptance and sign language mastery through questionnaires and interview protocol. The respondents were 33 parents from two Special Education National Schools deaf programs in Malaysia. Data have been analyzed through descriptive and theme analysis. The results showed that only three constructs were at the highest level of the mean, namely encouragement, affection and expectation of child's mathematics achievement whereas others at moderate level. Therefore, parents should take some actions to help child's mathematics learning such as increase the frequency of encouragement, emphasize the importance of mathematics, provided opportunity to apply basic mathematical facts in daily activities, visual reading materials, apply information technology, acceptance of the deaf child and strengthen the mastery of sign language. Subsequently, education ministry should pursue mathematics textbooks attached with sign language and produce mathematics exercise books in accordance with the format of examination moderation papers.
\end{abstract}

Keywords: Parents' engagement; Mathematics learning; Deaf child.

Mathematics across most subjects in school. Thus, children need to master mathematics during primary school so that they can achieve good achievement and live independently in future. Parents are the first person to interact with children either in academic or nonacademic areas. According to Marschark and Hauser (2012), the foundation of learning is built through communication, language and social interaction. Communication using languages that can be understood by parents and children is a positive interaction that promotes mathematics learning. Past studies have shown that parents play an important role in helping children in mathematics learning (Faridah, 2015; Braswell-Burris, 2010; Maimela \& Monyatsi, 2016). For example, parents who always give recognition, fully support, adequate supplies of learning tools and give guidance to children to complete homework, and well communication between parents and children. Therefore, parents' engagement is needed to support their child in better mathematics learning. Past studies have found that the presence of deaf child in families can cause family members, especially parents, to have difficulty in accepting the fact with emotional disturbances (Azleen, 2013; Edwards \& Crocker, 2008). As a result, the parent's services to the child will be affected. Additionally there is a language barrier to communicate with each other. The study of Movallali and Poorseyed (2015) found that parents with deaf child are more restrictive in child control, lack of enthusiasm to educate child and difficult to accept the presence of children as deaf individual. Thus, this study was conducted to survey the extent of parents' engagement in mathematics learning among deaf child with the research question as below.

To what extent is the parents engagement in mathematics learning among deaf child from the aspects of mathematical media resources support, encouragement, involvement in child's mathematical activity, child's experience in mathematics learning, reading mathematical materials with child, conducive learning environment, recognition and reward, affection, expectation of child mathematics achievement, child acceptance and sign language mastery?

\section{METHOD}

This is a cross-sectional survey with mix method sequential explanatory study. Questionnaire and interview protocol were used to collect information on parents' engagement in mathematics learning among deaf child of year 4, 5 and 6 . A total of 33 parents, consisted $17(51.5 \%)$ mothers and $16(48.5 \%)$ fathers, from two Special Education National Schools deaf program took part as respondents. All parents were non-hearing impaired. Their' socio economic status 
was at low level $23(69.7 \%)$ parents, followed by $8(24.2 \%)$ parents at moderate and $2(6.1 \%)$ parents at high. Communication mode of sign language stated $12(36.4 \%)$ parents, followed by combination of sign language and speech $11(33.3 \%)$ parents, and speech $10(30.3 \%)$ parents. Qualitative data were collected from two parents through interview protocol. The questionnaire was posted to the schools and returned it to researcher using the envelope provided. Data have been analysed through descriptive and theme analysis. The questionnaire was consisted two parts. Part A collected demographic information while Part B consists of eleven constructs. The questionnaire has been reviewed its validity and reliability. Face and content validity have been identified through five field and language experts, with Cohen Kappa's value 0.850. According to Landis and Kosh (1977), the value of Cohen Kappa is at very good level. The reliability of the questionnaire is sought with Cronbach's Alpha value 0.918. It showed that the questionnaire is an excellent instrument (Hair, Money, Page \& Samouel, 2007). The five levels of Likert Scale were used in questionnaire, namely "1 for strongly disagree (SD)", "2 for disagree (D)", "3 for less agree (LA)", "4 for agree (A)" and "5 for strongly agree (SA)". The level of interpretation for both item and construct used the interpretation of Jamil (2002) in which the score of low level is 1.00 to 2.33, moderate 2.34 to 3.66 and high 3.67 to 5.00 .

\section{FINDING AND DISCUSSION}

\section{Mathematical Media Resources Support}

Table 1 showed that parents' involvement in providing mathematical media resources support to deaf child were at moderate level (mean=2.83, s.d=1.41). The three items were also at moderate level namely, buy stationery (mean=2.97, s.d=1.51), buy mathematics books (mean=2.88, s.d=1.43) and provide mathematics hand-on materials (mean $=2.64, \mathrm{~s} . \mathrm{d}=1.54$ ). The percentages on scale of agree (A) and strongly agree (SA) for three items were at low level, as buy stationery $(36.3 \%)$, buy mathematics book (30.3\%), and provide mathematics hand-on materials (36.4\%). Percentage of buy mathematics book was the lowest (30.3\%) compared to the other two items.

The interview findings found that parents had bought basic fact book and flash card for their child other than mathematics book. However, they only bought mathematics book year 2 that were more focused on basic mathematical skills for their child who was in year 4, 5 or 6 . Additionally, parents have also provided hearing aids for child at age more than 2 years because they believed that hearing aid can assist the child in mathematics learning.

The education system in Malaysia has obliging deaf pupils to follow the same curriculum as typical pupils (Ministry of Education Malaysia, 2010). Deaf child needs to learn as typical pupils, only through sign language mediums. However, mathematics books bought by parents were not suit with their child of school year. There was because the mathematics books were difference in terms of mathematics curriculum, examination question

format and difficulty level. Thus, child faces difficulty to get used to answer mathematics questions according to their school year. The results of interview showed that parents were less likely to buy mathematics books which available in market because, existing books were less suitable for deaf child. For example, mathematics problem solving questions contain long sentences which differ if compared to mathematics examination paper. The child could not understand it. However, parents have taken positive steps to provide them hearing aids to help child in mathematics learning. Therefore, mathematics book which included exercise book should be revised in matching with the format of mathematics moderated exam papers that have been implemented since 2002 (Liong, 2012).

\section{Encouragement}

Refer to Table 2 as below, parents have encouraged child to learn mathematics at a high level (mean=3.78, $\mathrm{s} . \mathrm{d}=0.96)$. Both items of moral support (mean=4.03, $\mathrm{s} . \mathrm{d}=1.16)$ and encouragement $($ mean $=3.82, \mathrm{~s} . \mathrm{d}=1.10)$ showed mean at high level whereas item of motivational words (mean=3.48, s.d=1.22) at moderate level. Percentages on the scale of agree (A) and strongly agree (SA) found that three items were at moderate level namely, parents give moral support (69.7\%), motivational words $(63.7 \%)$ and encouragement $(63.6 \%)$.

Parents' interview found that they had given words of encouragement to their child but not consistently. There was a parent who always encouraged child to learn mathematics, and the other rarely gave words of encouragement. Although parents had encouraged child at high level as whole, but the practicing was inconsistent. According to Faridah (2015), parents those who always give encouragement, fully support, and encouragement can help the child to achieve good academic achievement. Therefore, parents should consistently encourage their child to learn mathematics.

\section{Involvement in child's mathematical activity}

Refer to Table 3 as above, parent involvement in child's mathematical activity was at moderate level (mean $=3.56$, s.d $=1.18$ ) as overall. Out of five items, three were at the moderate level while the other two were at high level. High level items were parents monitored homework (mean=3.67, s.d=1.29) and concern to child's mathematical learning (mean $=4.00$, $\mathrm{s} . \mathrm{d}=1.12$ ). 
Table 1. Frequency and percentage of mathematical media resources support

\begin{tabular}{lcccccccc}
\hline \multirow{2}{*}{ Item } & \multicolumn{4}{c}{ Level of Agreement/Percentage } & Mean & $\begin{array}{c}\text { Standard } \\
\text { deviation }\end{array}$ & $\begin{array}{c}\text { The level of } \\
\text { interpretation }\end{array}$ \\
\cline { 2 - 6 } & SD & D & LA & A & SA & & Moderate \\
Stationery & $8(24.2)$ & $5(15.2)$ & $8(24.2)$ & $4(12.1)$ & $8(24.2)$ & 2.97 & 1.51 & Moderate \\
Mathematics book & $7(21.2)$ & $7(21.2)$ & $9(27.3)$ & $3(9.1)$ & $7(21.2)$ & 2.88 & 1.43 & Moderate \\
$\begin{array}{l}\text { Provide } \\
\text { mathematics hand- } \\
\text { on materials }\end{array}$ & $12(36.4)$ & $5(15.2)$ & $4(12.1)$ & $7(21.2)$ & $5(15.2)$ & 2.64 & 1.54 & \\
\hline
\end{tabular}

Table 2. Frequency and percentage of encouragement

\begin{tabular}{|c|c|c|c|c|c|c|c|c|}
\hline \multirow[t]{2}{*}{ Item } & \multicolumn{5}{|c|}{ Level of Agreement/Percentage } & \multirow[t]{2}{*}{ Mean } & \multirow{2}{*}{$\begin{array}{l}\text { Standard } \\
\text { deviation }\end{array}$} & \multirow{2}{*}{$\begin{array}{l}\text { The level of } \\
\text { interpretation }\end{array}$} \\
\hline & SD & D & LA & $\mathbf{A}$ & SA & & & \\
\hline Motivational words & $3(9.1)$ & $5(15.2)$ & $4(12.1)$ & $15(45.5)$ & $6(18.2)$ & 3.48 & 1.22 & Moderate \\
\hline Moral support & $1(3.0)$ & $3(9.1)$ & $6(18.2)$ & $7(21.2)$ & $16(48.5)$ & 4.03 & 1.16 & High \\
\hline Encouragement & $1(3.0)$ & $3(9.1)$ & $8(24.2)$ & $10(30.3)$ & $11(33.3)$ & 3.82 & 1.10 & High \\
\hline & & & & & Overall & 3.78 & 0.96 & High \\
\hline
\end{tabular}

Table 3. Frequency and percentage of involvement in child's mathematical activity

\begin{tabular}{|c|c|c|c|c|c|c|c|c|}
\hline \multirow[t]{2}{*}{ Item } & \multicolumn{5}{|c|}{ Level of Agreement/Percentage } & \multirow[t]{2}{*}{ Mean } & \multirow{2}{*}{$\begin{array}{l}\text { Standard } \\
\text { deviation }\end{array}$} & \multirow{2}{*}{$\begin{array}{l}\text { The level of } \\
\text { interpretation }\end{array}$} \\
\hline & SD & D & $\mathbf{L A}$ & $\mathbf{A}$ & $\mathbf{S A}$ & & & \\
\hline $\begin{array}{l}\text { Discuss mathematics } \\
\text { questions }\end{array}$ & $7(21.2)$ & $4(12.2)$ & $7(21.2)$ & $8(24.2)$ & $7(21.2)$ & 3.12 & 1.45 & Moderate \\
\hline Monitor homework & $3(9.1)$ & $2(6.1)$ & $10(30.3)$ & $6(18.2)$ & $2(36.4)$ & 3.67 & 1.29 & High \\
\hline $\begin{array}{l}\text { Emphasize the } \\
\text { important of } \\
\text { mathematics }\end{array}$ & $4(12.1)$ & $2(6.1)$ & $11(33.3)$ & $5(15.2)$ & $11(33.3)$ & 3.52 & 1.35 & Moderate \\
\hline $\begin{array}{l}\text { Concern to } \\
\text { mathematical } \\
\text { learning }\end{array}$ & $1(3.0)$ & $2(6.1)$ & $8(24.2)$ & $7(21.2)$ & $15(45.5)$ & 4.00 & 1.12 & High \\
\hline \multirow[t]{2}{*}{$\begin{array}{l}\text { Accompany child } \\
\text { doing homework }\end{array}$} & $5(15.2)$ & $3(9.1)$ & $6(18.2)$ & $8(24.2)$ & $11(33.3)$ & 3.52 & 1.44 & Moderate \\
\hline & & & & & Overall & 3.56 & 1.18 & Moderate \\
\hline
\end{tabular}

The three items at the moderate level were parents discussed mathematics questions (mean $=3.12$, $\mathrm{s} . \mathrm{d}=1.45)$, emphasized the importance of mathematics (mean=3.52, s.d $=1.35$ ) and accompany child doing homework (mean=3.52, s.d=1.44). Meanwhile, on the scale of agree (A) and strongly agree (SA), all items were at moderate percentages. There were parents discussed mathematics questions $(45.4 \%)$, monitored homework $(54.6 \%)$, emphasized the importance of mathematics $(48.5 \%)$, concern to child's mathematical learning (66.7\%), accompany child doing homework $(57.5 \%)$.

The analysis of interview found that parents never stated the importance of mathematics to their child. However, it was found that family members, especially parents, have been directly involved in mathematics learning and taught them at home. They guided them to complete school task only. The results also found that the child's motivation to complete the mathematics exercises given by their teacher was high and would ask if he did not know how to solve the problem solving questions.

According to Liong (2012), mathematics is not only be applied to daily's activities, but it also help them to further their studies and as pre-requisites in career applications. However, the findings showed that most parents do not seen mathematics as an important subject. Interview analysis found that deaf child has selfmotivated in mathematics learning, therefore parents need to play a role to discuss, express the importance of mathematics and engage in child mathematics learning.

Additional mathematical exercises corresponding to their school year should be given to the child in order to master mathematics skills. This is because of interaction between parent and child can achieve a positive impact in terms of emotional, social, and linguistic development, subsequently mathematics achievement (Marschark \& Hauser, 2012). 
Table 4. Frequency and percentage of child's experience in mathematics learning

\begin{tabular}{|c|c|c|c|c|c|c|c|c|}
\hline \multirow[t]{2}{*}{ Item } & \multicolumn{5}{|c|}{ Level of Agreement/Percentage } & \multirow[t]{2}{*}{ Mean } & \multirow{2}{*}{$\begin{array}{l}\text { Standard } \\
\text { deviation }\end{array}$} & \multirow{2}{*}{$\begin{array}{l}\text { The level of } \\
\text { interpretation }\end{array}$} \\
\hline & SD & D & LA & $\mathbf{A}$ & SA & & & \\
\hline $\begin{array}{l}\text { Opportunity } \\
\text { basic facts }\end{array}$ & $7(21.2)$ & $4(12.1)$ & $9(27.3)$ & $6(18.2)$ & $7(21.2)$ & 06 & & Moderate \\
\hline $\begin{array}{l}\text { Provided mathematics } \\
\text { activity }\end{array}$ & $7(21.2)$ & $5(15.2)$ & $10(30.3)$ & $5(15.2)$ & $6(18.2)$ & 2.94 & 1.39 & Moderate \\
\hline $\begin{array}{l}\text { Mathematics } \\
\text { intervention program }\end{array}$ & $17(51.5)$ & $5(15.2)$ & $6(18.2)$ & $1(3.0)$ & $4(12.1)$ & 2.09 & 1.40 & Low \\
\hline $\begin{array}{l}\text { Try } m \\
\text { questi }\end{array}$ & $5(15.2)$ & $5(15.2)$ & $7(21.2)$ & $10(30.3)$ & $6(18.2)$ & 3.21 & 1.34 & Mod \\
\hline $\begin{array}{l}\text { Mathematics skills } \\
\text { application guidance }\end{array}$ & $5(15.2)$ & $1(3.0)$ & $12(36.4)$ & $7(21.2)$ & $8(24.2)$ & 3.36 & 1.32 & Moderate \\
\hline & & & & & Ove & 2.93 & 1.95 & Moderate \\
\hline
\end{tabular}

Table 5. Frequency and percentage of reading mathematical materials with child

\begin{tabular}{|c|c|c|c|c|c|c|c|c|}
\hline \multirow[t]{2}{*}{ Item } & \multicolumn{5}{|c|}{ Level of Agreement/Percentage } & \multirow[t]{2}{*}{ Mean } & \multirow{2}{*}{$\begin{array}{l}\text { Standard } \\
\text { deviation }\end{array}$} & \multirow{2}{*}{$\begin{array}{l}\text { The level of } \\
\text { interpretation }\end{array}$} \\
\hline & SD & $\overline{\mathbf{D}}$ & $\mathbf{L A}$ & $\overline{\mathbf{A}}$ & $\mathbf{S A}$ & & & \\
\hline Textbook & $6(18.2)$ & $6(18.2)$ & $10(30.3)$ & $6(18.2)$ & $5(15.2)$ & 2.94 & 1.32 & Moderate \\
\hline Additional materials & $6(18.2)$ & $6(18.2)$ & $8(24.2)$ & $7(21.2)$ & $6(18.2)$ & 3.03 & 1.38 & Moderate \\
\hline Reference books & $7(21.2)$ & $6(18.2)$ & $9(27.3)$ & $6(18.2)$ & $5(15.2)$ & 2.88 & 1.36 & Moderate \\
\hline & & & & & Overa & 2.95 & 1.27 & Moderate \\
\hline
\end{tabular}

\section{Child's experience in mathematics learning}

Table 4 showed parents provided child in mathematics learning experience at moderate level (mean=2.93, s.d=1.95). Out of the five items, four were at moderate level and one was at low level. The four items were parents to give child opportunity to use basic facts in daily activities (mean=3.06, $\mathrm{s.d}=1.43)$, provided mathematics activities at home (mean=2.94, s.d=1.39), giving child opportunity to answer mathematics questions (mean=3.21, s.d=1.34) and provide guidance for applying mathematics skills $($ mean $=3.36$, s.d=1.32). Item at low level was parents provided mathematics intervention program to their child (mean=2.09, s.d=1.40). Percentages on scale of agree (A) and strongly agree (SA), all five items posted at low percentages, ranging from $15.1 \%$ to $48.5 \%$. It showed that parents seldom gave opportunity to their child in applying basic fact in daily activities (39.4\%), doing mathematics activities at home (33.4\%), giving child the opportunity to answer mathematics questions (48.5\%), provide guidance for applying mathematics skills (45.4\%), and provided mathematics intervention program to their child (15.1\%).

The result of interview also found that parents did not fully provide the child's mathematics learning experience, especially child's opportunity of applying mathematics skills in daily activities such as shopping. The interview findings also found that the level of mastery in multiplication fact among deaf child was weak because he was not interested in learning multiplication fact and mathematics was not their favourite subject. However, the interview findings found that child could turns into interest in mathematics because of their mathematics teacher's teaching approaches.

According to Braswell-Burris (2010), early intervention is the support to pupil in achieving outstanding academic achievement when he is in higher schooling. Lack of exposure to mathematics at early stage can delay their mastery of mathematics skills when they are in higher school years. When a child is always be given the opportunity to apply basic facts in daily activities, this will lead them aware of the importance of basic facts. The contextual learning can have a positive effect in which the child is easier to understand the lesson in fun situations. The child is able to master multiplication fact if parents participate to teach them consistently. External factor such as teacher, which gets through interview findings, can change the child's interesting towards mathematics. Hence, parents also can alter the child's interesting in mathematics if they work together with their child's mathematics teacher to learn how to teach mathematics skills effectively.

\section{Reading mathematical materials with child}

Based on Table 5 as above, the findings showed that parents read mathematics materials with child at moderate level (mean=2.95, s.d=1.27). All three items were also at moderate level namely, reading textbook (mean=2.94, s.d=1.32), additional reading materials $($ mean $=3.03$, s.d $=1.38)$ and reference books (mean=2.88, s.d=1.36). In terms of percentages, on the scale of agree (A) and strongly agree (SA), all items were found to have a low percentage of reading textbook (33.4\%), additional reading materials (39.4\%) and reference books (33.4\%). 
Table 6. Frequency and percentage of conducive learning environment

\begin{tabular}{|c|c|c|c|c|c|c|c|c|}
\hline \multirow[t]{2}{*}{ Item } & \multicolumn{5}{|c|}{ Level of Agreement/Percentage } & \multirow[t]{2}{*}{ Mean } & \multirow{2}{*}{$\begin{array}{l}\text { Standard } \\
\text { deviation }\end{array}$} & \multirow{2}{*}{$\begin{array}{l}\text { The level of } \\
\text { interpretation }\end{array}$} \\
\hline & SD & D & $\mathbf{L A}$ & $\mathbf{A}$ & SA & & & \\
\hline $\begin{array}{l}\text { Comfortable } \\
\text { environment }\end{array}$ & $0(0.0)$ & $0(0.0)$ & $7(20.6)$ & $18(52.9)$ & $9(26.5)$ & 3.36 & 1.48 & Moderate \\
\hline Physical environment & $0(0.0)$ & $3(8.8)$ & $9(26.5)$ & $15(44.1)$ & $7(20.6)$ & 2.94 & 1.46 & Moderate \\
\hline Virtual environment & $0(0.0)$ & $1(2.9)$ & $15(44.1)$ & $13(38.2)$ & $5(14.7)$ & 2.94 & 1.50 & Moderate \\
\hline & & & & & Overall & 3.08 & 1.30 & Moderate \\
\hline
\end{tabular}

Table 7. Frequency and percentage of recognition and reward

\begin{tabular}{|c|c|c|c|c|c|c|c|c|}
\hline \multirow[t]{2}{*}{ Item } & \multicolumn{5}{|c|}{ Level of Agreement/Percentage } & \multirow[t]{2}{*}{ Mean } & \multirow{2}{*}{$\begin{array}{l}\text { Standard } \\
\text { deviation }\end{array}$} & \multirow{2}{*}{$\begin{array}{l}\text { The level of } \\
\text { interpretation }\end{array}$} \\
\hline & SD & D & LA & $\mathbf{A}$ & $\mathbf{S A}$ & & & \\
\hline Buy present & $10(30.3)$ & $5(15.2)$ & $4(12.1)$ & $5(15.2)$ & $9(27.3)$ & 2.94 & 1.64 & Moderate \\
\hline The words of praise & $1(3.0)$ & $2(6.1)$ & $5(15.2)$ & $12(36.4)$ & $13(39.4)$ & 4.03 & 1.05 & High \\
\hline \multirow[t]{2}{*}{ Give reward } & $10(30.3)$ & $3(9.1)$ & $5(15.2)$ & $9(27.3)$ & $6(18.2)$ & 2.94 & 1.54 & Moderate \\
\hline & & & & & Overall & 3.30 & 1.21 & Moderate \\
\hline
\end{tabular}

Interview analysis found that parents spent time reading mathematics with child, but only in a short period of time. This was because the child did not like to read, bored and has short concentration. Parents knew theirs' visual observations were high, but they were weak in literacy skills. They could encode the word but didn't understand the meaning. However, parents did not send their child to tuition class because no tuition center was suitable for them, such as teacher could not knew the sign language. Parents agree that the weakness of literacy is due to the lack of reading, and the mastery of literacy is closely related to the mathematics achievement because mathematics learning requires understanding in Malay language. That's why parents were saying that their child's mathematics achievement is weak.

The interview result was supported by Marschark and Hauser (2012) in part of visual observation of deaf pupil was sharper than other senses. Thus, parents need to provide interesting reading materials and visual manipulation in order to attract the child's attention. In addition, parents can read and do more mathematics exercise with child because according to Gagne (1985), the repetition method can reinforce that lesson for a longer period of time. Parents spend much time reading with child has close relationship with academic achievement (Jeynes 2011). Therefore, it is appropriate for parents to practice reading with child to improve mathematics achievement. However, existing mathematics books in the market are still less likely to meet the needs of deaf pupil, such as sign language are not included and most of the questions contain long sentences. Thus, the constraints have become a barrier to parents to help their children in mathematics learning effectively.

\section{Conducive learning environment}

Findings on Table 6 showed that conducive learning environment was at moderate level (mean=3.08, s.d=1.30). Similarly, all items in construct also stated at moderate level namely, parents provide a comfortable environment for child's mathematics learning (mean=3.36, s.d=1.48), physical environment is easy access to mathematics learning (mean $=2.94$, s.d=1.46), virtual learning is easy access to mathematics learning (mean=2.94, s.d=1.50). The percentages of agree (A) and strongly agree (SA) for all three items are also at moderate level such as the comfortable environment (79.4\%), the physical environment $(64.7 \%)$ and virtual environment $(52.9 \%)$. The interview findings found that parents didn't provide mathematics conducive learning space at home such as additional mathematics reading materials, there was only a study table and a school mathematics textbook. Internet facilities also were not available for child in mathematics learning.

Previous studies have shown significant relation between use of information technology such as surfing the web with academic achievement (Karal, 2015; Low, 2014). A variety of interesting mathematics information can be obtained through internet.

According to Marschark and Hauser (2012), deaf child has high visual observation, therefore the use of web pages is appropriate in mathematics learning. Additional reading materials can increase mathematics knowledge. Drilling in mathematics exercises enable child to master mathematics skills. Hence, conducive learning environment is necessary to assist child in mathematics learning. 
Table 8. Frequency and percentage of affection

\begin{tabular}{|c|c|c|c|c|c|c|c|c|}
\hline \multirow[t]{2}{*}{ Item } & \multicolumn{5}{|c|}{ Level of Agreement/Percentage } & \multirow[t]{2}{*}{ Mean } & \multirow{2}{*}{$\begin{array}{l}\text { Standard } \\
\text { deviation }\end{array}$} & \multirow{2}{*}{$\begin{array}{l}\text { The level of } \\
\text { interpretation }\end{array}$} \\
\hline & SD & D & LA & A & SA & & & \\
\hline Greeting & $0(0.0)$ & $1(3.0)$ & $3(9.1)$ & $13(39.4)$ & $16(48.5)$ & 4.33 & 0.78 & High \\
\hline $\begin{array}{l}\text { Care of child's } \\
\text { whereabouts }\end{array}$ & $0(0.0)$ & $0(0.0)$ & $3(9.1)$ & $10(30.3)$ & $20(60.6)$ & 4.52 & 0.67 & High \\
\hline Balanced diet & $0(0.0)$ & $0(0.0)$ & $6(18.2)$ & $6(18.2)$ & $21(63.3)$ & 4.45 & 0.79 & High \\
\hline Health & $0(0.0)$ & $3(9.1)$ & $0(0.0)$ & $9(27.3)$ & $21(63.3)$ & 4.45 & 0.90 & High \\
\hline & & & & & Overall & 4.44 & 0.71 & High \\
\hline
\end{tabular}

Table 9. Frequency and percentage of expectation of child mathematics achievement

\begin{tabular}{|c|c|c|c|c|c|c|c|c|}
\hline \multirow[t]{2}{*}{ Item } & \multicolumn{5}{|c|}{ Level of Agreement/Percentage } & \multirow[t]{2}{*}{ Mean } & \multirow{2}{*}{$\begin{array}{l}\text { Standard } \\
\text { deviation }\end{array}$} & \multirow{2}{*}{$\begin{array}{l}\text { The level of } \\
\text { interpretation }\end{array}$} \\
\hline & SD & D & LA & $\mathbf{A}$ & SA & & & \\
\hline High assessment & $2(6.1)$ & $3(9.1)$ & $4(12.1)$ & $12(36.4)$ & $12(36.4)$ & 3.79 & 0.77 & High \\
\hline High hoping & $1(3.0)$ & $3(9.1)$ & $1(3.0)$ & $10(30.3)$ & $18(54.5)$ & 3.62 & 0.74 & Moderate \\
\hline \multirow{2}{*}{$\begin{array}{l}\text { Believe their child } \\
\text { can obtain good } \\
\text { result }\end{array}$} & $0(0.0)$ & $0(0.0)$ & $4(12.1)$ & $15(45.5)$ & $14(42.4)$ & 3.71 & 0.68 & High \\
\hline & & & & & Overall & 3.71 & 0.71 & High \\
\hline
\end{tabular}

\section{Recognition and reward}

Refer to Table 7 as above, the level of recognition and reward was at moderate level (mean=3.30, $\mathrm{s} . \mathrm{d}=1.21$ ). Only item parent give the words of praised was at high level (mean=4.03, s.d=1.05). The other two items were at moderate level namely, parents buy present (mean=2.94, s.d=1.64) and give reward (mean $=2.94$, s.d=1.54). Percentages on scale agrees (A) and strongly agree (SA), two items namely, buy present $(42.5 \%)$ and reward $(45.5 \%)$ at moderate level, whereas give words of praise at high level $(75.8 \%)$. Interview found that child has more enthusiasm to learn mathematics after receiving parents' recognition and rewards, such as the words of praise and buy child's favourite items if he scored good result in mathematics test. However, rewards by parents only done in rarely.

The findings are supported by the study of Faridah (2015) that parents those who always give recognition such as praise and reward can improve the child's mathematics achievement. Praise words encourage child to be more eager to learn mathematics. Therefore, parents should give some rewards to their child if they achieved good in mathematics.

\section{Affection}

Findings on Table 8 as above showed that parents affection for deaf child was at high level of mean (mean $=4.44$, s.d $=0.71$ ) and percentages. The four items stated at high mean from 4.33 to 4.52 with standard deviation of 0.67 to 0.90 . The percentages of four item were at high level with percentages in between $81.5 \%$ to $90.9 \%$ namely, parents always give greeting to child
$87.9 \%$, parents' care of child's roundabouts $90.9 \%$, parents prepared balancing diet to child $81.5 \%$ and parents always look after child in good health $90.6 \%$. The interview found that parents gave fully affection to their child such as they were patient to treat them, teach, guide to control emotions, and be polite when talking to others. Parents also were willing to hear child's feelings.

The above findings are supported by the study of Nancy and Safani (2015) that also found parents' caring for child was at high level. Close relationship between parents and child allow them for sharing their feelings and opinions as well as providing emotional comfort for child to be more willing to learn mathematics. Parent's neat caring enables child having a good health and an active mind. Therefore, children are able to concentrate on theirs' mathematics learning. Through the tightly relationship, the child will always ask his parents when they face problems in mathematics learning. As a result, child will obtain better result in mathematics achievement.

\section{Expectation of child mathematics achievement}

Table 9 showed that parents gave their child's mathematics achievement expectation at high level (mean=3.71, s.d=0.71). Out of the three items, only item of giving high hope in mathematics achievement at moderate level (mean=3.62, s.d=0.74), while the other two items were at high level such as parents give high assessment in mathematics achievement (mean=3.79, $\mathrm{s} . \mathrm{d}=0.77$ ) and believe their child can obtain good result in mathematics achievement (mean $=3.71, \mathrm{sd}=0.68$ ). 
Table 10. Frequency and percentage of child acceptance

\begin{tabular}{lccccccccc}
\hline \multirow{2}{*}{ Item } & \multicolumn{5}{c}{ Level of Agreement/Percentage } & Mean & $\begin{array}{c}\text { Standard } \\
\text { deviation }\end{array}$ & $\begin{array}{c}\text { The level of } \\
\text { interpretation }\end{array}$ \\
\cline { 2 - 6 } & SD & D & LA & A & SA & & & \\
\cline { 1 - 1 } $\begin{array}{l}\text { Accept the reality of } \\
\text { having deaf child }\end{array}$ & $0(0.0)$ & $6(18.2)$ & $9(27.3)$ & $15(45.5)$ & $3(9.1)$ & 3.45 & 0.90 & Moderate \\
$\begin{array}{l}\text { No disappointed of } \\
\text { having deaf child }\end{array}$ & $0(0.0)$ & $5(15.2)$ & $16(48.5)$ & $8(24.2)$ & $4(12.1)$ & 3.33 & 0.89 & Moderate \\
$\begin{array}{l}\text { No inferior of } \\
\text { having deaf child }\end{array}$ & $0(0.0)$ & $8(24.2)$ & $14(42.4)$ & $7(21.2)$ & $4(12.1)$ & 3.21 & 0.96 & Moderate \\
$\begin{array}{l}\text { No ashamed of } \\
\text { having deaf child }\end{array}$ & $0(0.0)$ & $12(36.4)$ & $9(27.3)$ & $9(27.3)$ & $3(9.1)$ & 3.09 & 1.01 & Moderate \\
\hline & & & & & Overall & 3.27 & 0.81 & Moderate \\
\hline
\end{tabular}

Table 11. Frequency and percentage of sign language mastery

\begin{tabular}{lcccccccc}
\hline \multirow{2}{*}{ Item } & \multicolumn{9}{c}{ Level of Agreement/Percentage } & Mean & $\begin{array}{c}\text { Standard } \\
\text { deviation }\end{array}$ & $\begin{array}{c}\text { The level of } \\
\text { interpretation }\end{array}$ \\
\cline { 2 - 6 } & SD & D & LA & A & SA & & Moderate \\
\cline { 1 - 1 } $\begin{array}{l}\text { Proficient in Malay } \\
\text { Hand-coding }\end{array}$ & $2(6.1)$ & $13(39.4)$ & $15(45.5)$ & $2(6.1)$ & $1(3.0)$ & 2.61 & 0.83 & Moderate \\
$\begin{array}{l}\text { Proficient in } \\
\begin{array}{l}\text { Malaysia Sign } \\
\text { Language }\end{array}\end{array}$ & $2(6.1)$ & $12(36.4)$ & $17(51.5)$ & $2(6.1)$ & $0(0.0)$ & 2.58 & 0.71 & \\
$\begin{array}{l}\text { Proficient in } \\
\text { American Sign } \\
\text { Language }\end{array}$ & $6(18.2)$ & $16(48.5)$ & $9(27.3)$ & $2(6.1)$ & $0(0.0)$ & 2.21 & 0.82 & Low \\
\hline & & & & & & & & \\
\hline
\end{tabular}

However, if viewed on the scale of agree (A) and strongly agree (SA), the percentages for the two items were at high percentage namely, giving high hope in mathematics achievement $(84.8 \%)$ and believe their child can obtain good result in mathematics (87.9\%). While item of parents give high assessment in mathematics achievement at moderate percentage $(72.8 \%)$.

The findings of the interview found that parents have done self-reflection on their teaching or explanation in child's mathematics lesson. It was found that deaf child still lack confidence in solving mathematics questions. Parents also found that the child had some personal problems such as forgetful, tired, short and weak memory in mathematics skills learning. However, parents still gave a high level of mathematics achievement expectation to their child because they believed that child can achieve better result in mathematics through drilling more exercises.

The above findings are supported by the study of Spencer and Marschark (2010). According to Spencer and Marschark (2010), deaf child often face problems as unconfident when doing problem solving questions due to memory and concentration capacity are weak. However, the findings of this study showed that parents were still positive-minded to give a positive mathematics achievement expectation for their child. The continuous efforts of parents in teaching mathematics are a great action to help their child to achieve good mathematics achievement. Hence, the mathematics achievement of deaf child can be enhanced if parents be responsibility to keep on teaching them mathematics skills.

\section{Child acceptance}

Table 10 showed that the level of child acceptance by parents was at moderate level $($ mean $=3.27, \mathrm{~s} . \mathrm{d}=0.81)$. The four items were also at moderate level namely, parents can accept the reality of having deaf child (mean=3.45, s.d=0.90), parents don't disappointed of having deaf child (mean $=3.33$, s.d $=0.89$ ), parents do not inferior of having deaf child (mean=3.21, $\mathrm{s.d}=0.96$ ) and parents do not ashamed of having deaf child (mean=3.09, s.d=1.01). On the scale of agree (A) and strongly agree (SA), the percentages of parents can accept the reality of having deaf child at moderate level $(54.6 \%)$, whereas parents do not disappointed of having deaf child $(36.3 \%)$, parents do not inferior of having deaf child (33.3\%) and parents don't ashamed of having deaf child (36.4\%). The interview founds that parents hard to accept the fact that having deaf child with sadness, shock and startled feeling during several early years. The period of time to accept the reality of having deaf child was from two to five years. The descriptive analysis found that most parents are less 
likely to accept the fact that their child is a deaf child with feeling of disappointed, inferior and ashamed.

The findings of this study are similar to the findings of previous studies (Azleen, 2013; Vinayak, Dhanoa \& Vinayak, 2016). According to Azleen (2013) study, the acceptance deaf child by family members especially parents, can assist the child's academic progress. Therefore, the negative feelings must be eliminated, in opposite to focus on their academic development in future.

\section{Sign language mastery}

Refer to Table 11, overall, parents mastered sign language at moderate level ( mean $=2.46, \mathrm{~s} . \mathrm{d}=0.63$ ). Out of three, an item parents proficient in American Sign Language was at low level (mean=2.21, $\mathrm{sd}=0.82$ ), whereas the other two items were at moderate level namely, parents proficient in Malay Hand-coding ( $m e a n=2.61, \mathrm{sd}=0.83$ ) and parents proficient in Malaysia Sign Language $(\mathrm{mean}=2.58, \mathrm{sd}=0.71)$. On the scale of agree (A) and strongly agree (SA), the three items stated a very low level namely, parents' proficiency in Malay Hand-coding (9.1\%) and the other two had the same percentages namely, parents' proficiency in American Sign Language and Malaysia Sign Language (6.1\%). The interview findings showed that parents' mastery of Malay Hand-coding and Malaysia Sign Language were at moderate level. However, parents were enthusiasm to learn sign language. Unfortunately, they did not have the information regarding sign language learning courses. The school did not conduct sign language courses or workshops for parents. They stated that the effective mode of communication used at home was combination of sign language and speech. On their opinion, Malay Hand-coding language was seen to be more effective than Malaysia Sign Language and American Sign Language. If parents are unskilled in sign language, the process of mathematics learning information transmission is difficult to deliver to deaf child effectively.

According to Jeynes (2011), the parents proficiency in sign language influences the effectiveness of communication which lead to academic achievement. When there is a barrier in communication, parents can not even express the concept and application of mathematics skills clearly. Parents should urge the school to conduct sign language workshops for them. Good collaboration between parents and school, especially mathematics teacher can help them to master the sign language of a particular mathematical term. Without mastering sign language well, it is impossible for child to master the skills in mathematical learning. Therefore, child's mathematics achievement can be affected.

\section{CONCLUSION AND SUGGESTION}

\section{Conclusion}

This study examined parents' engagement from eleven constructs in mathematics learning through survey method using questionnaire and interview protocol. There are mathematical media resources support, encouragement, involvement in child's mathematical activity, child's experience in mathematics learning, reading mathematical materials with child, conducive learning environment, recognition and reward, affection, expectation of child's mathematics achievement, child acceptance and sign language mastery. Overall, there were only three constructs stated at high level namely encouragement, affection, expectation of child's mathematics achievement whereas eight constructs at moderate level.

\section{Suggestion}

Based on the result study, it is suggested for parents to take some actions to help their child in mathematics learning namely, increase the encouraging frequency, state the importance of mathematics, provide the opportunity to apply basic facts in daily activities, visual manipulation of reading materials and buy books which are appropriate to child's school year, using an interesting mathematics learning materials through website searching, acceptance of deaf child and strengthen their mastery of sign language. for Education Ministry to revise mathematics textbook attached with sign language and publish mathematics exercise books in accordance with the format of examination papers. Mutual co-operation between parents, school and education ministry can help to improve the effectiveness of mathematics learning as well as increase mathematics achievement among deaf child.

\section{REFERENCES}

Azleen, M. B. (2013). Persdektif Anak Berkerperluan Khas Terhadap Penerimaan-Penolakan Ibu Dan Bapa. Tesis Sarjana Pendidikan, Fakulti Pendidikan, Universiti Kebangsaan Malaysia.

Braswell-Burris, P. A. (2010). Factors Affecting the Educational and Personal Success of Deaf or Hard of Hearing Individuals. Tesis Dr. Fal, Faculty of San Diego State University.

Edwards, L., \& Crocker, S. (2008). Psychological Processes in Deaf Children with Complex Needs: An Evidence-Based Practical Guide London: Jessica Kingsley Publishers. 
Faridah, M. S. (2015). Amalan Kreativiti, Gaya Kognitif Kreatif, Pengaruh Faktor Persekitaran Dan Pencapaian Pelajar Pintar Akademik. Tesis Dr. Fal., Fakulti Pendidikan, Universiti Kebangsaan Malaysia.

Gagne, R. M. (1985). The conditions of learning and theory of instruction. 4th Edition. New York: Holt, Rinehart and Winston, Inc.

Hair, J., Money, A., Page, M., \& Samouel, P. (2007). Research Methods for Business. England: John Wiley \& Sons.

Jamil, A. (2002). Pemupukan budaya penyelidikan di kalangan guru di sekolah: satu penilaian. Tesis Doktor Falsafah, Fakulti Pendidikan, Universiti Kebangsaan Malaysia.

Jeynes, W. H. (2011). Parental Involvement and Academic Success. New York: Routledge.

Karal, H. (2015). The effects of a technology-aided learning environment on the improvement of a primary special education School. Educational Research and Reviews, 2908-2918.

Landis, J., \& Kosh, G. G. (1977). The measurement of observer agreement for categorical data. Biometrics, 33(1), 159-174.

Liong, K. T. (2012). Kaedah Pengajaran Jemari Ajaib (KPJA) Dalam Pembelajaran Sifir Murid Bermasalah Pendengaran. Tesis Sarjana Pendidikan, Fakulti Pendidikan, Universiti Kebangsaan Malaysia.

Low, G. S. (2014). Pembangunan Perisian Matematik Bulatan I dan Kesan Penggunaannya Terhadap Murid Bermasalah Pendengaran. Tesis Sarjana Pendidikan (Pendidikan Khas). Fakulti Pendidikan dan Pembangunan Manusia, Universiti Pendidikan Sultan Idris.
Maimela, M., \& Monyatsi, P. P. (2016). Strategies for improving the academic performance of students in Botswana primary schools. World Journal of Educational Research, 3(1), 157-181.

Marschark, M., \& Hauser, P. C. (2012). How Deaf Children Learn: What Parents and Teacher Need to Know. Oxford University Press.

Ministry of Education Malaysia. (2010). Surat Pekeliling /Ikhtlsas Bilangan Ii Tahun 2010: Pelaksanaan Kurikulum Standard Sekolah Low (KSSR) Tahap Satu Mulai 2011. KP(BPSHSDDK) 201/005/01/jld, 3(5).

Movallali, G., \& Poorseyed, S. R. (2015). Attachment styles and perceived parenting styles: A comparison of hearing impaired adolescents and normal adolescents. Journal Social Science Human Studies, 1(3), 7-12

Nancy, A., \& Safani, B. (2016). Tahap perkembangan emosi murid bermasalah pendengaran daripada aspek kawalan diri, kemahiran sosial dan motivasi. Seminar Antarabangsa Pendidikan Khas Rantau Asia Tenggara Siri Ke-6 2016, 297-302.

Spencer, P. E., \& Marschark, M. (2010). EvidenceBased Practice In Educating Deaf And Hard of Hearing Students. Oxford University Press.

Vinayak, S., Dhanoa, S. K., \& Vinayak, R. (2016). Relationship of hopelessness, depression and quality of life in mothers of persons with disabilities. International Journal of Innovation and Applied Studies, 17(1): 306-311. 